\title{
The Role of Local Spiritualism Approach to Counter Woman Involvement in Violent Extremism
}

\author{
A Darmayani ${ }^{1}, K_{\text {Aditama }}{ }^{2}$ \\ Rumah Kebangsaan \\ darmayani.azrina@gmail.com ${ }^{1}$, krishna.aditama@,outlook.com ${ }^{2}$
}

\begin{abstract}
This paper aimed to explain the role of local spiritualism approach to counter woman involvement in violent extremism through Mother's recitation clubs. Fitri Ardiana, a 21 years old woman was instantaneously notorious due to her radical movement to Wiranto's attack on October 2019. Her contribution to the operation was not significant but her involvement and status as a woman had blown the media publication. This was not the first case of woman action in violent extremism. Religion was accused as the major reason that led to their actions. Therefore, this instrument can also be used as two-edged swords. Providing counter-narratives has always seen as the best practice to cure its proliferation. One of the methods that was practiced by Rumah Kebangsaan was through injecting the messages through mother's recitation club - where counter-narrative was exercised by discussing the Quran with preachers who had a good reputation and decent knowledge in understanding the Quran. The method used to support the argument of this paper was through narrative analysis approach on 3 recitation communities in Jakarta that will be used to assess how mother's recitation clubs can act as a strategy to Counter Violent Extremism (CVE). The results of the study showed that close-personal connections within the community provided stronger trust to promote healthy alternatives as a strategy to deconstruct terrorist and violent extremist narratives. This paper will exercise the role of localizing this attempt and how it can truly contribute counter violent extremism for women.
\end{abstract}

Keywords : Woman and Violent Extremism, Recitation, Counter Narratives

\section{INTRODUCTION}

Since its emergence, ISIS managed to attract millions of followers across the world including Indonesia. ISIS propagate caliphate or living condition where shariah law as the ideal way of life and all people have to be a devout Muslim. ISIS also eliminate people who refused to join them and declare war against those who are in their way of making a country that is ideal according to them. Millions of people becoming followers, thousand went to join them to fight or just want to live under the caliphate at ISIS-controlled area. About 600 Indonesian went to join them. There is no specific background of people who went to join ISIS. Everyone from male and female, young or elderly people, poor and rich, even those the ones who were considered educated pledge their support or bai'at to ISIS.

ISIS emergence also caused the rise of Islam conservative value that also happened in Indonesia. ISIS sympathizers spread their value through social media like Facebook and Twitter and also messenger apps like WhatsApp. They spread content like photos and videos of what it is like to live in the area that uphold caliphate and cruel video of them punishing people who refused to join and convert to their version of Islam. The process of radicalizing people is also 
happening in public recitation. The preacher glorified why we must remove Pancasila and use caliphate system that deemed better. Hate speech towards non-Muslim leaders like former Governor of Jakarta Basuki Tjahaya Purnama or a public figure that been seen removing her hijab like Rina Nose is increasingly common.

The speech that the preachers delivered is the process of what the Organization for Security and Co-Operations for Europe called violent extremism and radicalization that leads to terrorism (VERLT). VERLT is a dynamic process whereby an individual comes to accept terrorist violence as a possible, perhaps even legitimate, course of action. This may eventually, but not necessarily, lead this person to advocate, act in support of, or to engage in terrorism.

After the process of understanding, accepting and spreading the value of ISIS narratives, some people will go far beyond that. Some people attacked the police because they defend the Government who refused their request. Several attacked to the police station had been done by individuals or a group of people who were identified as people who already pledged to ISIS. These people who had attempted to attack police office were not affiliated to any organization. They were simply people who support ISIS movement to uphold the caliphate.

The role of women participating in terrorist attacks is increasing. In the recent attack in Medan or in Surabaya for example, women also involved in suicide bombing action. In Surabaya, women become one of the actors of suicide bomber alongside her children. In Sibolga, we can observe that women can be more dangerous than men in defending the action of terrorism. Women involvement is still minor compared to the men, but it does not mean that their action is insignificant compared to their men. They could be the ones who carry on the mission, like the one Sibolga. Women are not less radical compare to men in action.

Leebarty Taskarina in her book titled Perempuan dan Terorisme, she explained that these women initially just wife to their terrorist husband. They started to take more role in helping their husband because women are considered less striking, this become big advantage because they can easily hide or trick the authority or society. In Muslim culture, women sit on a very vulnerable position. It is a must for women to follow what their husband does and considered forbidden to deny their order. This is an advantage for men to use women to help or event continue their actions if the husband falls during the fight. The belief of what they do is jihad, less willingness for women to refuse not to join an action.

In other scenario, there are others who do not want to fight for ISIS or join terrorist attack. They just want to live in area where the caliphate is being upheld. These people also went to ISIS-controlled territory in Syria. Some went alone, others brought their family. Dhania and her family was an example. Frustrated by the current condition of the country, she was interested in the idea of living like how the prophet used to live. Where is no injustice, no hunger, no poverty. From social media, she found a person who was willing to guide her. This person taught about religion and answering all her doubts where she managed to pursue her family of 26 people to go to Syria and live under the caliphate order.

\section{RESEARCH METHOD}

This paper disposed narrative analysis approach, a form of qualitative analysis in which the analyst focuses on how the respondents impose order on the flow of experience in their lives and thus make sense of events and actions in which they have participated [1]. The coding of narrative analysis revolves around reading the stories and classifying them into general patterns or the "big picture". The object of the study is 3 Mother's recitation clubs in Jakarta. This method specifically observed and conducted deep interview analysis to representative of woman in each club as random sampling. Every data gathered was examined by exercising narrative 
analysis model that generalizes the data which can provide an overview of the system's functionality.

\section{RESULTS AND DISCUSSIONS}

This part of the paper will explain the result of analysis on how local spiritualism approach through Mother's recitation clubs can act as a strategy to Counter Violent Extremism (CVE). In this part of results statement, the process can be seen in 4 different roles. The first is the culture that pose spiritualism approach that was believed as a channel of most answers and recitation club was an 'accommodative' guide. Second, the trust that had been built in the community, that made it easier to inject the healthy value by issuing the right guru as a technique to engage religious actors in countering violent extremism. Third was the sustainable engagement within the community works as a strong support system that can be an "alert" to tackle violent extremism. Lastly, woman tendency to spread word of mouth could be an initial stage to identify, predict and respond to potential vulnerabilities to extremism - specifically to her peers and family.

The local spiritualism approach that applied in 3 mother's recitation club in Jakarta was overtaking the existing club that accommodated by local woman community. On regular basis, Rumah Kebangsaan helped to provide preachers and built a concept that could be relevant to counter VE narratives that not merely focusing on onerous religious topic - but also focusing on various discussions on how to keep the tolerance, live in peace with other human or empowering their surroundings in the value of Islam. This activity had been implemented for a year when at least the recitation event was held once every month in every club. A sound starting point for designing this counter-narrative campaign was through developing a sound understanding of (the context of) 'the problem', underlying determinants, where communication can potentially contribute to a solution [2].

To commence the discussions, a common understanding on how violent extremism was propitious to advance as a part of radicalization outcomes could not be comprehended by a single path. In addition, each case of VERLT must be observed as the results of a unique combination of the personal trajectory and psychology of given individual and the (possibly enabling) environment in which that individual lives [3]. Individual socio-psychological factors, social factors, political factors, culture and identity crisis, trauma and other trigger mechanisms, group dynamics, radicalizers, and social media were stated as various factors by The European Commission's Radicalization Awareness Network (RAN). This study further revealed that culture and identity crisis, group dynamics, social media, and radicalizers, as the major factors that need to be covered through the approach that applied in Mother's Recitation Club that objected to our study.

The first roles answered the dilemma of culture and identity crisis. Alvara Research Center released a statement that expressed that $95 \%$ of Indonesians put religious values as an important part of their daily life. This statement was proven by the zestful participation of Indonesians in various religious activities. $28,8 \%$ of Muslims in Indonesia attend religious events at least once a week. One of the most popular mediums was Mother's recitation clubs.

The fact that previously revealed was supported by the idea that most Muslims and so did Muslims woman always prioritize the answers of every life question to religious reference. Their weekly participation in religious events or communities were an asset to influence their opinions toward everything in life. The way of life in general to a specific topic such as parenting, thinking, working, praying, even dressing up were majorly answered as a manifestation of their religious belief. The form of its abstraction leads to a condition when the crisis of life happened, they would seek advises from religious representative - which in 
Indonesia mostly forms as mother's recitation clubs. This community has been perceived as an accommodative guide that can help them to get a better spiritual life. While this community also frequently being used as a machine to inject VE propaganda, utilizing mother's recitation clubs to deconstruct the ideology to counter and serve healthier narratives was a strategy to kill the virus right in the place it spread.

The second role that highlighted the trust that had been established in the community made it easier to inject the healthy value by issuing the right guru as a part of engaging religious actors to directly counter violent extremism responded the problem that served in a context of group dynamic factor. The pre-existing friendship and kinship helped to create a 'comfortable' environment for women to learn and challenge their life questions. This personal connection benefited the effort to influence the opinions to be way more acceptable. Once the trust was built, the attempt to counter the negative thoughts by using charismatic religious actors or leaders is effort-averted.

The group dynamic factor positioning ustadz or religious guru to do more than something that only related to religion [4]. As the same pattern found in the field research and supported the argument of Peter Mandaville and Melissa Nozell in the Special Report of United States Institutes of Peace titled "Engaging Religion and Religious Actors in Countering Violent Extremism" that stated that religious leaders primary role was also to provide counterideological messages or theological antidotes to extremist interpretations of religion that transcend spaces, activities, and institutions that conventionally demarcated as religious. Their bridging was not straightforwardly talking about tackling the VE, but instead of conveying the relevant context in a conversation about daily life. This counter narrating strategy was applied through a softer approach that impacted the absence of reluctance during the implementation.

Badan Pusat Statistik on a workshop that collaborated with Ministry of Female Empowerment and Child Protection that discussed "Data and Information Publication related to Woman Empowerment and Child Protection" announced the press release that overview the high number of woman involvement in social media. $79,92 \%$ of women in Indonesia used the internet for accessing their social media networks.

The vital existence of women in social media, however, was quite risky due to the great amount of radical or violent extremism accounts and contents in social media. Until mid-2019, 1.285 social media accounts had been taken down because of its implication that led and provoke ideology and action related to radicalism, terrorism, and violent extremism [5]. This current condition actually can also be prevented by strengthening sustainable engagement within the mother's recitation clubs community to works as a support system that can be an "alert" to tackle violent extremism.

The mother's recitation clubs also connected themselves in the online social media community such as Facebook and WhatsApp. They talked in a continuous manner that allowed them to chat about everything. The topic could be as simple as morning greetings, schedule of the next meetings, updates from each member's life or cooking to the complicated ones such as political preferences or opinions. They shared most of the things in the social media channel that furthermore could be employed as an alert when the indicator of topics was showing an inclination of negative narratives in this context VE propaganda. The club coordinator played a huge part to filter any kind of information that may influence the member's perspectives. This channel also could perform as a hub to remind each other when someone began showing deviated acts. The emotional connections that had been constructed bolstered the effort of counter-narratives to be more admissible for those influenced by the early stage of VE reception.

The fourth role was to help identify, predict and respond to potential vulnerabilities to extremism - especially in the scope of her peers and family, by the natural psychological desire 
of woman - telling stories. This role could truly counter the situation when the presence of radicalizer existed. Any exposure to hate preachers and those who prey on people's vulnerabilities and grievances, channeling recruits into VERLT through methods such as persuasion, pressure, and manipulation could be resolved through the power of women ability to tell story. The messages and learning they gathered from the club were implemented in their daily life. That sharing was a part of its advocations that usually targeted their other friends outside of the club and the closest group in their life - their own family. Spending time once a week to catch up about life and forwarding the counter VE messages that they got from the club to friends and family were influential to make a greater impact on countering VE's movement that started from mother's recitation club. On top of that, this role could not only cover the power of utilizing this local spiritualism approach to protect woman involvement in VE but also to the wider audience - the husband and the children.

\section{CONCLUSIONS}

Utilizing local spiritualism approach by injecting counter-narratives messages to tackle VE in woman's recitation club can be seen as a fulfilling effort to diminish the triggering factor of their possible involvement. The fact that the mother's recitation club was usually seen as an "accommodative" guide for them to answer questions about their life highlighted that this channel was the right one to influence their mind. The existing emotional connections that had been built for such a long term also made the club became a trusted place to issue the right guru or religious leader that can help then to guide themselves to move away from VE traps. Continuous engagement in social media could also act as an alert when someone in the community was identified exposed by VE. Mother's recitation club has a power to trigger women to identify, predict, and respond to any probability that her closer circle might be endangered by VE influence. In a shorter way, the approach that being applied in mother's recitation club involved close-personal connections between women to accept the counternarratives messages and provide support system for them to advocate the messages to their closest environment to deconstruct terrorists and violent extremist narratives. 


\section{REFERENCES}

[1] R. K. Schutt, "Qualitative Data Analysis" in Investigating the Social World: The Process and Practice of Research, California, Sage Publications, 2012, pp. 339-341.

[2] J.J. Van Erteen, B. Doosje, E. Konjin, B. de Graf, and M. de Goede, Developing a Social Media Response to Radicalization: The Role of Counter Narratives in Prevention of Radicalization and De-radicalization, VU Amsterdam, University of Amsterdam and Utrecht University, 2017. p.2.

[3] Organization for Security and Co-operation in Europe (OSCE), Understanding the Role of Gender in Preventing and Countering Violent Extremism and Radicalization That Lead to Terrorism, OSCE Secretariat, 2019, p. 29.

[4] P. Mandaville and M. Nozell, "Engaging Religion and Religious Actors in Countering Violent-Extremism," United States Institute of Peace, Washington, DC 20037, August 2017.

[5] Ministry of Communication and Information Technology Official Website, "Hapus 1.285 Akun Medsos, Kominfo Terus Sisir Konten Radikal”, Kominfo-Sorotan Media [Daring], Tersedia : https://kominfo.go.id/content/detail/13128/hapus-1285-akunmedsos-kominfo-terus-sisir-konten-radikal/0/sorotan media [Diakses 20 November 2019] 